\title{
OcCurrence of Pulmonicola cochleotrema (syn. Cochleotrema cochleotrema) (Digenea: Opisthotrematidae) in Antillean manatees (Trichechus manatus manatus) IN BRaZIL ${ }^{1}$
}

\author{
Vitor luz Carvalho $23,{ }^{*}$, Ana Carolina Oliveira de Meirelles 3 , Monica Regina Alves Motta ${ }^{4}$, Débora Castelo \\ Branco de Sousa Colares Maia², Maria Verônica Moraes Campello ${ }^{5}$ and Claudia Maria Leal Bevilaqua ${ }^{2}$
}

\begin{abstract}
AвstRAct - The present work reports the first record of the trematode parasite Pulmonicola cochleotrema in Antillean manatee (Trichechus manatus manatus) in Brazil. Out of 15 necropsied manatees in the State of Ceará, the parasite was found in the nares, trachea and bronchi of four animals (two juvenile males, one juvenile female and one adult female), for a prevalence of $26.7 \%$. The parasites were identified based on morphological features observed in the 38 collected specimens. No pathological manifestations were observed associated with the presence of the parasites in the present study. The prevalence observed in the State of Ceará and the lack of reports of this parasite species in other states of northeastern Brazil may suggest the existence of an isolated population, a higher occurrence of the intermediate host, or differences in the feeding habits of the manatees.
\end{abstract}

REsumo - Este trabalho apresenta o primeiro registro do parasito trematóide Pulmonicola cochleotrema, em peixe-boi-marinho (Trichechus manatus manatus) no Brasil. De 15 peixes-bois necropsiados no Estado do Ceará, foram encontrados parasitos nas narinas, traquéias e brônquios de quatro animais (dois machos juvenis e duas fêmeas, sendo uma adulta e uma juvenil), com prevalência de $26.7 \%$. A identificação dos parasitos foi feita com base nas características morfológicas observadas de 38 espécimes coletados. Não foram observados sinais patológicos relacionados com a presença dos parasitos no presente estudo. A prevalência observada para o Estado do Ceará e a ausência de registro deste parasito em peixes-bois-marinhos de outros Estados do Nordeste, pode sugerir a existência de uma população isolada, uma maior abundância de hospedeiros intermediários ou diferenças nos hábitos alimentares dos animais.

Kerwords: Parasites, Pulmonicola cochleotrema, antillean manatee, Trichechus manatus manatus, Brazil.

\section{Introduction}

The order Sirenia is comprised of the essentially herbivorous aquatic mammals that inhabit shallow coastal waters, rivers and estuaries in tropical and subtropical regions (Hartman, 1979; Marsh et al., 1986, Domning, 2002). In Brazil, this order is represented by two out of the four living species: the Antillean manatee (Trichechus manatus manatus), one of two subspecies of the West Indian manatee (T. manatus), and the Amazonian manatee (Trichechus inunguis) (IBAMA, 2001).

The Antillean manatee is considered the most threatened species of aquatic mammal in Brazil, with a discontinuous distribution along the northern and northeastern coast of the country. The main causes of mortality include previously employed hunting practices, capture in fishing nets, and the stranding of calves (Oliveira et al., 1990'; Parente et al., 2004; Meirelles, 2008). Besides anthropogenic threats, manatees can develop many infectious (VergaraParente et al., 2003; Bossart et al., 2004; Woodruff et al., 2005) and parasitic (Blair, 1981; Dubey et al., 2003) diseases that may compromise their health status and cause death (Borges, 2007). The species is classified as 'critically endangered' (i.e. extremely high risk of extinction in the wild within the immediate future) by the Action Plan for Aquatic Mammals of Brazil (IBAMA, 2001). Captive individuals, stranded calves and carcasses found on beaches have been the main sources of information on the biology, physiology and diseases of the Antillean manatee (D'Affonseca Neto and Vegara-Parente, 2007).

The sirenian parasitic fauna is mainly composed of protozoans and roughly 25 identified species of trematodes and nematodes, most of them exclusive to this order (Dailey, 2001; Raga et al., 2002). In Brazil, Cryptosporidium spp. oocyst infections have been reported in Antillean and Amazonian manatees (Borges et $a l ., 2007 a ; b)$. There are reports of parasitic helminthes infecting T. inunguis (Mullins et al., 20037; Borges et al., $2007^{8}$ ), but there are no documented records for $T$. manatus manatus in the country.

\footnotetext{
${ }^{1}$ Received on 11 September 2008. Accepted on 14 July 2009. Managed by Nélio Barros / Diane Gendron.

${ }^{2}$ Programa de Pós-Graduação em Ciências Veterinárias, Faculdade de Veterinária, Universidade Estadual do Ceará - UECE, Avenida Paranjana, 1700, Campus do Itapery, Fortaleza - Ceará, Brasil, CEP 60740-903.

${ }^{3}$ Associação de Pesquisa e Preservação de Ecossistemas Aquáticos - AQUASIS.

SESC Iparana, Praia de Iparana, S/N, Caucaia - Ceará, Brasil CEP 61600-000.

${ }^{4}$ Médica Veterinária Autônoma.

${ }^{5}$ Laboratório de Parasitologia, Faculdade de Veterinária, Universidade Estadual do Ceará - UECE, Avenida Paranjana, 1700, Campus do Itapery, Fortaleza - Ceará, Brasil, CEP 60740-903.

* Corresponding author, e-mail: vitorluz@yahoo.com.br.

${ }^{6}$ Oliveira, E.M.A., Langguth, A., Silva, K.G., Soavinski, R.J. and Lima, R.P. (1990) Mortalidade do peixe-boi marinho (Trichechus manatus) na costa nordeste do Brasil. Pages 191-196 in Abstracts, IV Reunión de Trabajo de Especialistas en Mamíferos Acuaticos da America del Sur, 12-15 November, Valdivia, Chile.

${ }^{7}$ Mullins, M.C., Lazzarini, S.M., Picanço, M.C.L., Knoff, M. and Freire, N.M.S. (2003) Trematoda da família Opisthotrematidae parasito de Trichechus inunguis (Sirenia: Trichechidae), em Balbina no Estado do Amazonas, Brasil. Page 25 in Abstracts, XVIII Congresso Brasileiro de Parasitologia, 26-29 August, Rio de Janeiro, Brasil.

${ }^{8}$ Borges, J.C.G., Alves, L.C., Lima, M.M., Faustino, M.A.G. and Marmontel, M. (2007) Ocorrência de Helmintos Gastrointestinais em peixes-boi amazônicos (Trichechus inunguis). IV Seminário Anual de Pesquisas do Instituto de Desenvolvimento Sustentável Mamirauá, Tefé, Brazil.
} 
The objective of the present paper is to report the first occurrence of the parasite Pulmonicola cochleotrema (syn. Cochleotrema cochleotrema) in the Antillean manatee (T. manatus) in Brazil.

\section{Material and Methods}

Carcasses of Antillean manatees were recovered by Associação de Pesquisa e Preservação de Ecossistemas Aquáticos (Aquasis) from January 1992 to April 2008. The carcasses were transported to the Marine Mammal Rehabilitation Centre (CRMM/SESC Ceará), where necropsies and collection of biological material were carried out in fresh and moderate decomposed animals, following the recommendations of Geraci and Lounsbury (2005) and Vergara-Parente (2005a).

During these procedures, a careful search for parasites was performed in all organic systems. Nostrils, trachea, bronchi and lungs were opened and washed and the collected content was strained. Whenever possible, the digestive tract was opened, from the esophagus to the rectum, and the content was also collected and strained. The mucosae were inspected in search of adhered parasites.

The helminthes were collected, fixed and preserved in AFA (93 parts $70 \%$ alcohol, 5 parts $40 \%$ formaldehyde and 2 parts acetic acid). The age class of the infected animals was estimated by total length, based on the data published for the Florida manatee (Marmontel, 1993).

The collected material was sent to the Laboratory of Parasitology of Ceará State University (UECE), where specimens were stained by Amato's method (1985), clarified in phenol for mounting on temporary slides, and identified using an optical microscope. Measurement of the internal structures in millimeters was accomplished using Image $\mathrm{J}^{\mathrm{TM}}$ software. The character measurement range is followed in parenthesis by the mean value. The terminology used for parasite description follows Blair (1981). Prevalence (ratio between the number of infected and the number examined animals), as well as intensity (number of parasites in one host) were calculated according to Bush et al. (1997).

\section{Results}

Seventeen carcasses of Antillean manatees were recovered during the study (Table 1). In two carcasses, necropsy was not viable due to the advanced stage of decomposition. Out of the 15 necropsied animals, parasites were found in the nares, trachea and bronchi of four animals (Figure 1).

The parasites presented oval bodies with $5-11 \mathrm{~mm}$ $(7.55 \mathrm{~mm})$ of total length and $3-7 \mathrm{~mm}(4.58 \mathrm{~mm})$ of maximum width. They were ventrally concave and dorsally convex. The entire margin of the body contained a strong muscular fringe. We observed a ventral, subterminal oral sucker, measuring $0.70-1.31 \mathrm{~mm}$ $(0.96 \mathrm{~mm})$ in diameter, with transverse opening (Figure 2). The esophagus measured $0.20-0.50 \mathrm{~mm}(0.31 \mathrm{~mm})$. Intestinal ceca were dorsal to all other organs, sinuous, and ending near the posterior extremity. Testes were rounded, approximately similar in size, measuring 0.48 $1.07 \mathrm{~mm}(0.81 \mathrm{~mm})$ at their largest diameter (Figure 3 ). Ovaries were irregular, but not deeply lobated, measuring $0.35-0.74 \mathrm{~mm}(0.48 \mathrm{~mm})$ in diameter, located to the right or to the left of the midline, and were intercecal and pretesticular. Scarce vitellaria were distributed in irregular follicles and intercecal. The uterus was intercecal, with the opening close to the male aperture. The morphological features observed led to the identification of Pulmonicola cochleotrema Poche 1926.

Based on this sample, prevalence of $P$. cochleotrema was $26.7 \%$ for the State of Ceará. The infection intensity was 176 for animal 02S0111/10, 20 for animals 02S0111/34 and 02S0112/38, and eight for animal 02S0112/43 (Table 1).

\section{Discussion}

Pulmonicola cochleotrema is a digenetic trematode that belongs in the family Opisthotrematidae. This species is currently thought to be synonymous with Cochleotrema cochleotrema (Blair, 2005). It is found mainly in the nares, though it can also be found in the trachea and bronchi of manatees (Beck and Forrester, 1988). The species has been reported to parasitize T. manatus in the United States, Guyana, Puerto Rico, Dominican Republic, and elsewhere in the Caribbean (Beck and Forrester, 1988; Mignucci-Giannoni et al., 1999). In Brazil, the only record of this parasite is in the intestine of a T. inunguis kept in captivity in Balbina, State of Amazonas (Mullins et al., 20036).

In the animals examined in the present study, no macroscopic pathological signs were observed related to the presence of $P$. cochleotrema. Sirenian parasites are rarely associated with clinical manifestations (Bossart, 2001). However, severe infections caused by $P$. cochleotrema have been reported in an adult Florida manatee, resulting in chronic rhinitis and pulmonary edema, and in a juvenile female, resulting in chronic ulcerative epiglottitis and parasitic pneumonia (Beck and Forrester, 1988). These findings were reported in animals that presented infection intensity of 250 and 490, respectively. Such values are greater than the ones found in the present study, where the highest intensity was 176.

The life cycles of sirenian parasites have not been determined; however, it is thought that nematodes of sirenians may use crustaceans as intermediate hosts, which can be incidentally consumed during grazing (Jueco, 1977; Beck and Forrester, 1988). The trematode species present in sirenians likely use mollusks as intermediate hosts and are infected by the incidental ingestion of the larval stages on contaminated food plants (Blair, 1981; Beck and Forrester, 1988; Yamaguti, 1971). 
Table 1. Specimens of Antillean manatee stranded dead in the State of Ceará from 1992 to 2008 for which helminthes were found parasitizing the respiratory system.

\begin{tabular}{|c|c|c|c|c|c|c|c|c|}
\hline $\begin{array}{l}\text { RECORD } \\
\text { NUMBER }\end{array}$ & $\begin{array}{l}\text { PLACE OF } \\
\text { STRANDING }\end{array}$ & $\begin{array}{l}\text { GEOGRAPHIC } \\
\text { COORDINATES }\end{array}$ & DATE & SEX & $\begin{array}{l}\text { SIZE } \\
(\mathrm{m})\end{array}$ & $\begin{array}{c}\text { AGE } \\
\text { CLASS }\end{array}$ & CAUSA MORTIS & $\begin{array}{l}\text { PULMONICOLA } \\
\text { PRESENCE }\end{array}$ \\
\hline 02S0111/01 & Icaraí, Caucaia & $\begin{array}{l}S 03^{\circ} 39^{\prime} 53^{\prime \prime} \\
W 38^{\circ} 40^{\prime} 53^{\prime \prime}\end{array}$ & $03 / 1992$ & 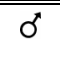 & $<1.75$ & Calf & Undetermined & No \\
\hline 02S0110/02 & $\begin{array}{l}\text { Parajuru, } \\
\text { Beberibe }\end{array}$ & $\begin{array}{l}\text { S } 04^{\circ} 22^{\prime}, \\
\text { W } 37^{\circ} 51^{\prime}\end{array}$ & 01/14/1995 & NI & --- & Juvenile & Undetermined & No \\
\hline 02S0111/07 & $\begin{array}{l}\text { Porto das Dunas, } \\
\text { Aquiraz }\end{array}$ & $\begin{array}{l}\mathrm{S} 03^{\circ} 50^{\prime}, \\
W 38^{\circ} 23^{\prime}\end{array}$ & 02/17/1999 & $\sigma$ & 1.54 & Calf & Undetermined & No \\
\hline 02S0111/10 & Quixaba, Aracati & $\begin{array}{l}\mathrm{S} 04^{\circ} 31^{\prime}, \\
\text { W } 37^{\circ} 39^{\prime}\end{array}$ & $07 / 07 / 2000$ & $\delta$ & 2.69 & Adult & Incidental Capture & Yes \\
\hline 02S0112/13 & $\begin{array}{l}\text { Fontainhas, } \\
\text { Aracati }\end{array}$ & $\begin{array}{l}\mathrm{S} 04^{\circ} 37^{\prime}, \\
\text { W } 37^{\circ} 36^{\prime}\end{array}$ & $01 / 27 / 2001$ & 웅 & 2.72 & Adult & Incidental Capture & No \\
\hline 02S0111/16 & $\begin{array}{l}\text { Retiro Grande, } \\
\text { Icapuí }\end{array}$ & $\begin{array}{l}\mathrm{S} 04^{\circ} 38^{\prime} 26^{\prime \prime}, \\
\text { W } 37^{\circ} 32^{\prime} 20^{\prime \prime}\end{array}$ & $03 / 31 / 2001$ & 0 & 1.39 & Calf & Incidental Capture & No \\
\hline 02S0110/24 & $\begin{array}{l}\text { Praia do Ceará, } \\
\text { Icapuí }\end{array}$ & $\begin{array}{l}\mathrm{S} 04^{\circ} 50^{\prime}, \\
\text { W } 37^{\circ} 15^{\prime}\end{array}$ & $07 / 22 / 2004$ & NI & 2.7 & Adult & Undetermined & No \\
\hline $02 S 0110 / 25$ & $\begin{array}{l}\text { Canoa } \\
\text { Quebrada, } \\
\text { Aracati }\end{array}$ & $\begin{array}{l}\mathrm{S} 04^{\circ} 30^{\prime}, \\
\text { W } 37^{\circ} 43^{\prime}\end{array}$ & $09 / 17 / 2004$ & NI & 1.3 & Calf & Undetermined & No \\
\hline $02 S 0112 / 29$ & $\begin{array}{l}\text { Retirinho, } \\
\text { Aracati }\end{array}$ & $\begin{array}{l}\mathrm{S} 04^{\circ} 47^{\prime} 31^{\prime \prime}, \\
\text { W37 } 35^{\prime} 9^{\prime \prime}\end{array}$ & $11 / 08 / 2005$ & 우 & 2.13 & Juvenile & Undetermined & No \\
\hline $02 S 0112 / 33$ & $\begin{array}{l}\text { Majorlândia, } \\
\text { Aracati }\end{array}$ & 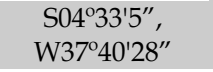 & $03 / 22 / 2006$ & ㅇ & 3.03 & Adult & Incidental capture & No \\
\hline 02S0111/34 & $\begin{array}{l}\text { Canoa } \\
\text { Quebrada, } \\
\text { Aracati }\end{array}$ & $\begin{array}{l}\text { S } 04^{\circ} 30^{\prime}, \\
\text { W } 37^{\circ} 43^{\prime}\end{array}$ & $03 / 22 / 2006$ & $\sigma^{\prime \prime}$ & 2.03 & Juvenile & Incidental capture & Yes \\
\hline 02S0112/36 & Redonda, Icapuí & 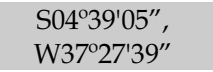 & $09 / 26 / 2006$ & 웅 & 3.07 & Adult & Incidental capture & No \\
\hline $02 S 0112 / 38$ & $\begin{array}{l}\text { Retiro Grande, } \\
\text { Icapuí }\end{array}$ & $\begin{array}{l}\mathrm{S} 04^{\circ} 38^{\prime} 31.7^{\prime \prime}, \\
\text { W37 } 37^{\circ} 42.9^{\prime \prime}\end{array}$ & $02 / 25 / 2007$ & 우 & 3.18 & Adult & Boat Collision & Yes \\
\hline $02 \mathrm{~S} 0111 / 40$ & $\begin{array}{l}\text { Ponta Grossa, } \\
\text { Icapuí }\end{array}$ & $\begin{array}{c}\text { S04 } 38^{\prime} 00.7^{\prime \prime} \\
\text { W } 37^{\circ} 30^{\prime} 46.9^{\prime \prime}\end{array}$ & $04 / 05 / 2007$ & 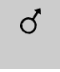 & 1.17 & Calf & Malnourishment & No \\
\hline 02S0112/41 & $\begin{array}{l}\text { Praia das Placas, } \\
\text { Icapuí }\end{array}$ & 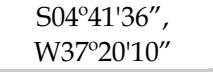 & 04/15/2007 & 우 & 1.06 & Calf & Malnourishment & No \\
\hline $02 \mathrm{~S} 0111 / 42$ & Redonda, Icapuí & $\begin{array}{r}\text { S } 04^{\circ} 38^{\prime} 48,5, \\
\text { W } 37^{\circ} 28^{\prime} 40,1^{\prime \prime}\end{array}$ & $02 / 13 / 2008$ & $\sigma$ & 1.15 & Calf & $\begin{array}{c}\text { Cardiorespiratory } \\
\text { arrest/ } \\
\text { Malnourishment }\end{array}$ & No \\
\hline $02 S 0112 / 43$ & $\begin{array}{l}\text { Ilha Grande, } \\
\text { Barroquinha }\end{array}$ & $\begin{array}{c}\text { S } 02^{\circ} 57^{\prime} 42,3^{\prime \prime}, \mathrm{W} \\
41^{\circ} 18^{\prime} 05,9^{\prime \prime}\end{array}$ & $04 / 06 / 2008$ & 우 & 2.53 & Adult & Undetermined & Yes \\
\hline
\end{tabular}

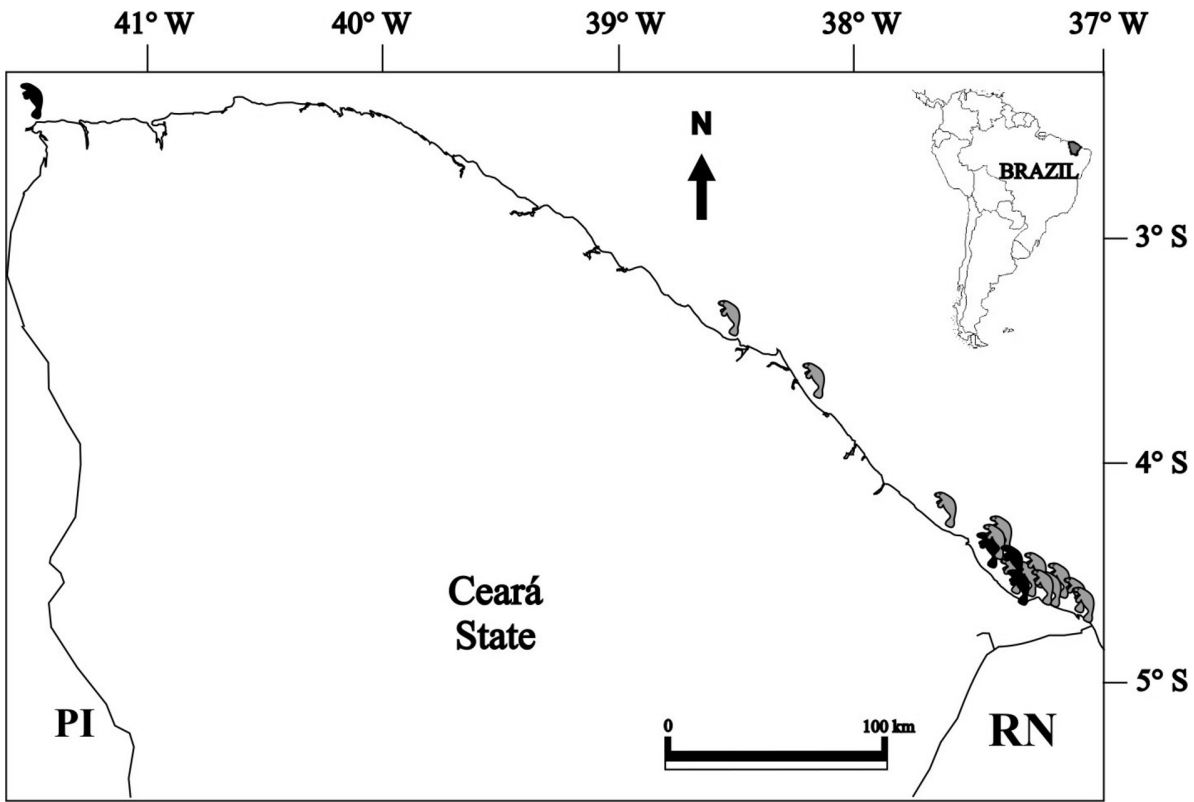

Figure 1. Distribution of strandings of dead Antillean manatees (manatee symbols) in the State of Ceará. Black manatees indicate the presence of Pulmonicola cochleotrema. 


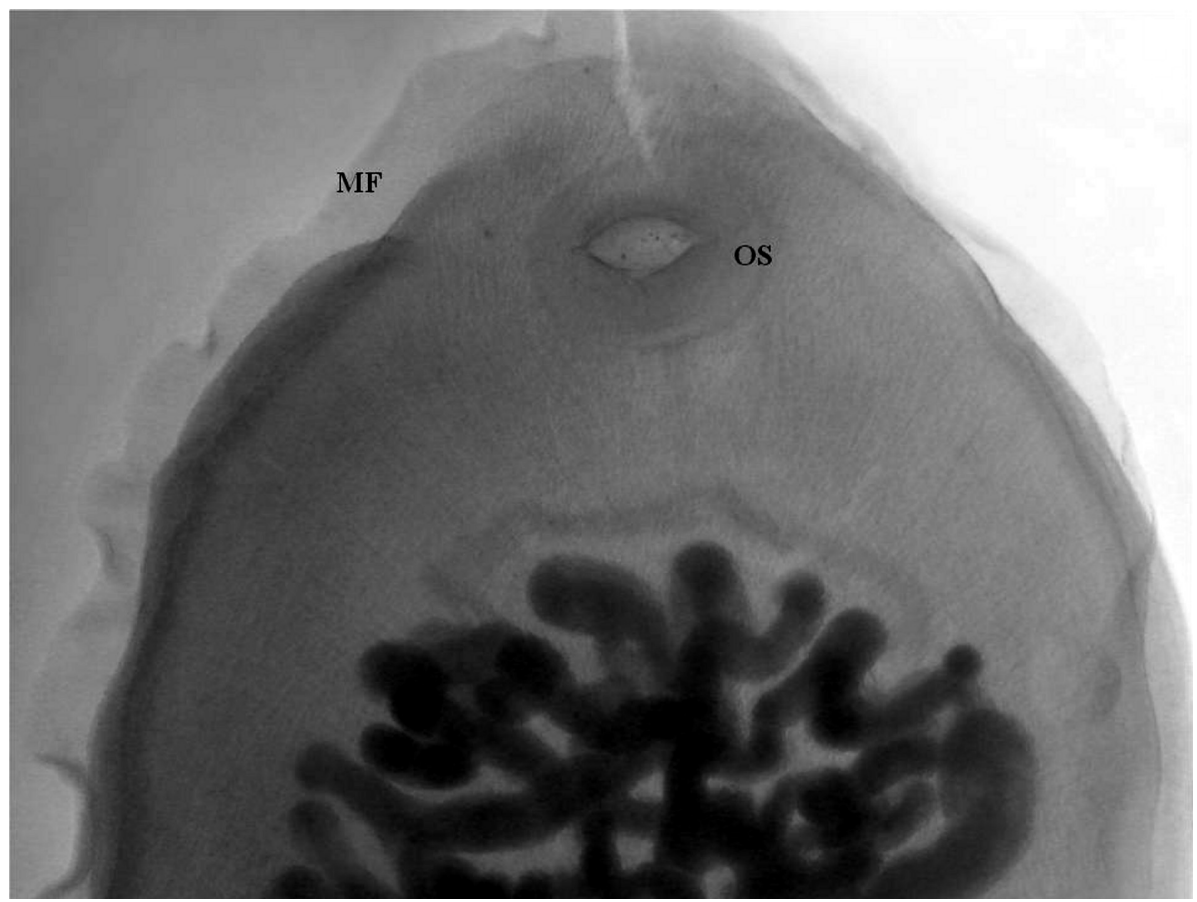

Figure 2. Anterior portion of Pulmonicola cochleotrema, collected from an Antillean manatee from the State of Ceará, showing muscular fringe (MF) and oral sucker (OS), with transversal opening (10X).

Figure 3. Posterior portion of Pulmonicola cochleotrema, showing the rounded testes $(\mathrm{T})$ and ovary (O) (10X).

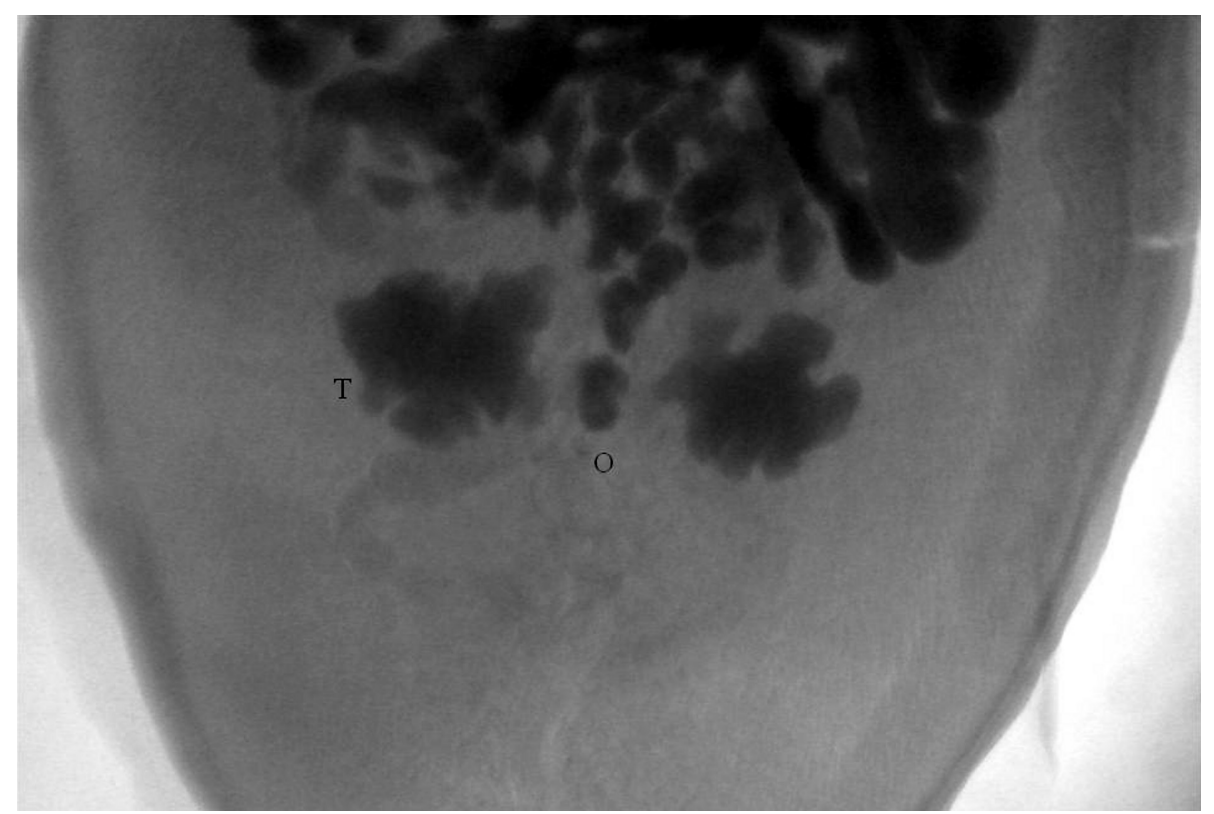

Beck and Forrester (1988) observed that larger and older animals hosted a greater number of parasites, probably due to the larger habitat available within the host and the increased chances of exposure according to the age. Conversely, calves with less exposure time to the infective stages also consume less vegetation than the older animals.

In the present study, the infected manatees were two juvenile males, one juvenile female and one adult female. Despite the small number of samples, the findings are compatible with Beck and Forrester (1988), considering that $35.3 \%$ of the animals necropsied in their study were calves and no parasites were observed in these specimens.

Despite ongoing research efforts, the presence of helminthes has not been previously reported in $T$. manatus in Brazil. The Projeto Peixe-Boi/ICMBio has monitored the occurrence of gastrointestinal helminthosis in Antillean manatees kept in captivity since 1991, and none of the samples collected and 
examined during necropsies have contained eggs, larva or adult of any parasite species (Vergara-Parente, 2005b). Beck and Forrester (1988) reported differences in the prevalence of $P$. cochleotrema from different locations in Florida; however, it was not known if this reflected a variation in the distribution or abundance of definitive and intermediate hosts, or variations in the habitat, such as water salinity, temperature and other factors. The prevalence of $26.7 \%$ of $P$. cochleotrema in the State of Ceará may suggest the existence of an isolated population of this parasite, a greater abundance of intermediate hosts or differences in the feeding habits of the manatees. It is important to emphasize that occurrence and intensity may be underestimated since these parasites can be easily lost from the nares in the carcasses when they are in the water or during transport (Beck and Forrester, 1988). Moreover, the largest research effort in recent years may have contributed to underestimate prevalence, since the parasites were found during the period when collection protocols have been improved.

Many parasites are used as natural markers of biological and environmental phenomena because their transmission is closely related to host and environmental characteristics. They can be used as biological indicators of phylogeny, local migration, distribution, disease, stock identity and social behavior (Geraci and Lounsbury, 2002). However, in this study, the number of evaluated animals from the location where the infection was diagnosed is insufficient for the utilization of $P$. cochleotrema as a biological marker. Thus, further study is necessary to determine whether P. cochleotrema infection can be used in this way. Increased research efforts, improvement of parasite collection protocols, training of specialized personnel and investigation of food content of animals from different locations will facilitate this process. The increasing threats to the manatees and the reduced number of individuals present on the Brazilian coast make research on this species of great importance for their conservation, including the detection of parasitic agents.

\section{Acknowledgements}

We thank João Carlos Gomes Borges, Jociery Einhardt Vergara-Parente, Fernanda Menezes de Oliveira e Silva and Cristine Pereira Negrão Silva for their reviews and important suggestions; the Aquasis team, for their work recovering and performing manatees necropsies; Dr. Cláudio Cabral Campello for contributions in preparing the photographs; Dr. Cathy Beck and other referees for their comments and suggestions to improve this manuscript; and the Coordenação de Aperfeiçoamento de Pessoal de Nível Superior (CAPES) for financial support.

\section{References}

Амato, J.F. (1985) Manual de técnicas para a preparação de coleções zoológicas. 8. Platelmintos (temnocefálidos, trematódeos, cestóides, cestodários) e acantocéfalos. Sociedade Brasileira de Zoologia, São Paulo, Brazil.

BeCK, C. AND Forrester, D.J. (1988) Helminths of the Florida manatee, Trichechus manatus latirostris, with a discussion and summary of the parasites of sirenians. Journal of Parasitology 74(4): 628-637.

BlaIR, D. (1981) The Monostome Flukes (Digenea: Families Opisthotrematidae Poche and Rhabdiopoeidae Poche) Parasitic in Sirenians (Mammalia: Sirenia). Australian Journal of Zoology Supplementary Series 81: 1-54.

BlaIr, D. (2005) Family Opisthotrematidae Poche, 1926. Pages 401-406 in Jones, A., BraY, R.A. And Gibson, D.I. (Eds) Keys to Trematoda, Vol 2. CABI International and The Natural History Museum, London, UK.

Borges, J.C.G. (2007) Cryptosporidium spp. (Tyzzer, 1907) em peixes-boi marinhos (Trichechus manatus) (Linnaeus, 1758) e peixesboi amazônicos (Trichechus inunguis) (Natterer, 1883) no Brasil. MSc. Thesis. Universidade Federal Rural de Pernambuco, Recife, Brazil. 121pp.

Borges, J.C.G., Alves, L.C., Lima, D.S., Luna, F.O., Aguilar, C.V.C., Vergara-Parente, J.E., Faustino, M.A.G., Lima, A.M.A. AND MARMONTEL, M. (2007a) Ocurrencia de Cryptosporidium spp. en manatí amazônico (Trichechus inunguis, Natterer, 1883). Biotemas 20 (3): 63-66.

Borges, J.C.B., Alves, L.C., Faustino, M.A.G. and Lima, A.M.A. (2007b) Ocorrência de Cryptosporidium spp. em peixes-boi marinhos (Trichechus manatus) e funcionários envolvidos no manejo da espécie. Estudos de Biologia 29 (66): 33-41.

Bossart, G.D. (2001) Manatees. Pages 939-958 in Dierauf, L.A. AND GulLand, F.M.D. (Eds) Handbook of marine mammal medicine. CRC Press, Boca Raton, USA.

Bossart, G.D., Meisner, R.A., Rommel, S.A., Lightsey, J.D., Varela, R.A. and Defran, R.H. (2004) Pathologic findings in Florida manatees (Trichechus manatus latirostris). Aquatic mammals 30 (3): 434-440.

Bush, A.O., Lafferty, K.D., Lotz, J.M., Shostak, A.W. (1997) Parasitology meets ecology in its own terms: Margolis et al. Revisited. Journal of Parasitology 83: 575-583.

D’ Affonseca Neto, J.A. and Vergara-Parente, J.E. (2007) Sirenia (Peixe-boi-da-Amazônia, Peixe-boi-marinho). Pages 701-714 in Cubas, Z.S., Silva, J.C.R., Catão-Dias, J.L. (Eds) Tratado de animais selvagens - medicina veterinária. Roca, São Paulo, Brazil.

Dailey, M.D. (2001) Parasitic diseases. Pages 357-379 in Dierauf, L.A. AND Gulland, F.M.D. (Eds) Handbook of marine mammal medicine. CRC Press, Boca Raton, USA.

Domning, D.P. (2002) Sirenian evolution. Pages 1083-1086 in Perrin, W.F., Würsig, B. ANd TheWISsen, H.G.M. (Eds) Encyclopedia of marine mammals. Academic Press, San Diego, USA.

Dubey, J.P., Zarnke, R., Thomas, N.J., Wong, S.K., VAN BonN, W., Briggs, M., Davis, J.W., Ewing, R., Mense, M., KwoK, O.C.H., Romand, S. AND Thulliez, P. (2003). Toxoplasma gondii, Neospora caninum, Sarcocystis neurona, and Sarcocystis canis-like infections in marine mammals. Veterinary Parasitology 116: 275-296.

Geraci, J.R. AND Lounsbury, V.J. (2002) Health. Pages 562-570 in Perrin, W.F., Würsig, B. ANd Thewissen, H.G.M. (Ed.) Encyclopedia of marine mammals. Academic Press, San Diego, USA. 
GERACI, J.R. AND LOUnSBURY, V.J. (2005). Marine Mammals Ashore: A Field Guide for Strandings, Second edition. National Aquarium in Baltimore, Baltimore,MD, USA. 371 pp.

Hartman, D.S. (1979) Ecology and behavior of the manatee (Trichechus manatus) in Florida. American Society of Mammalogists Special Publication 5. 153pp.

IBAMA (2001) Mamíferos aquáticos do Brasil : Plano de ação versão II. Instituto Brasileiro do Meio Ambiente e dos Recursos Naturais Renováveis, Brasília, Brazil. 102 pp.

JueCo, N.L.(1977) The nematode Paradujardinia halicoris in the sea cow in the Philippines. Philippine Journal of Biology 6: $257-262$.

Marmontel, M. (1993) Age determination and population biology of the Florida manatee, Trichechus manatus latirostris. Ph.D. Dissertation, University of Florida, Gainesville, USA. 407 pp.

Marsh, H., O'SheA, T.J. And Best, R.C. (1986) Research on sirenians. AMBIO 15 (3): 177-180.

Meirelles, A.C.O. (2008) Mortality of Antillean manatee, Trichechus manatus manatus, in the State of Ceará, Northeastern Brazil. Journal of the Marine Biological Association of the United Kingdom 88 (4):1133-1137.

Mignucci-Giannoni, A.A., Williams JR., E.H., Toyos-GonZÁlez, G.M., Perez-Padilla, J., Rodriguez-Lopez, M.A., Vega-Guerra, M.B. and Ventura-GonzÁlez, M. (1999) Helminths from a stranded manatee in the Dominican Republic. Veterinary Parasitology 81: 69-71.
Parente, C.L., Vergara-Parente, J.E. and Lima, R.P. (2004) Strandings of Antillean manatees, Trichechus manatus manatus, in Northeastern Brazil. The Latin American Journal of Aquatic Mammals 3 (1): 69-75.

Raga, J.A., Fernández , M., Balbuena, J.A. And Aznar, J. (2002) Parasites. Pages 867-876 in Perrin, W.F., Würsig, B. AND Thewissen, H.G.M. (Eds) Encyclopedia of marine mammals. Academic Press, San Diego, USA.

Vergara-Parente, J.E., Sidrim, J.J.C., Teixeira, M.F.S., Marcondes, M.C.C. AND Rocha, M.F.G (2003). Salmonellosis in an Antillean manatee (Trichechus manatus manatus) calf: a fatal case. Aquatic Mammals 29 (1): 131-136.

Vergara-Parente, J.E. (2005a) Parte-II Necropsia de cetáceos e sirênios: Sirênios. Pages 185-203 in Vergara-Parente, J.E (Ed). Protocolo de conduta para encalhes de mamíferos aquáticos. IBAMA, Recife, Brazil.

Vergara-Parente, J.E. (2005b) Parte-I Resgate, reabilitação e soltura: Sirênios. Pages 83-97 in Vergara-Parente, J.E (Ed.) Protocolo de conduta para encalhes de mamíferos aquáticos. IBAMA, Recife, Brazil

WoOdrufF, R.A., Bonde, R.K., Bonilla, J.A. AND ROMERO, C.H. (2005). Molecular identiûcation of a papilloma virus from cutaneous lesions of captive and free-ranging Florida manatees. Journal of Wildlife Diseases 41 (2): 437-441.

Yamaguti, S. (1971). Synopsis of Digenetic Trematodes of Vertebrates. Keigaku Publishing Company, Tokyo, Japan. 1074 pp. 